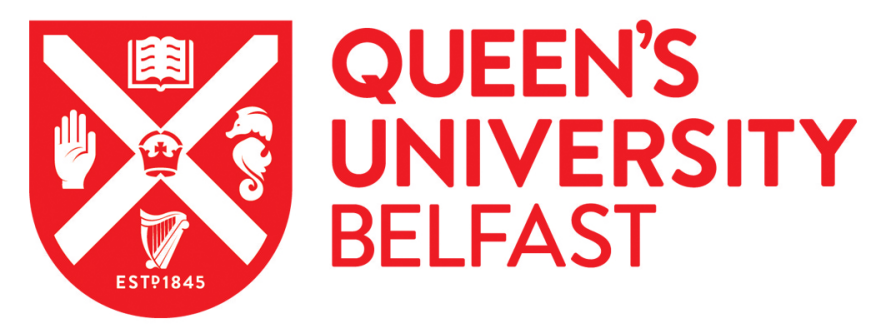

\title{
Nursing, leadership and academia: Passing the baton
}

Darbyshire, P., Thompson, D. R., Hungerford, C., \& Lauder, W. (2020). Nursing, leadership and academia: Passing the baton. Nurse Education Today, 89, [104400]. https://doi.org/10.1016/j.nedt.2020.104400

\section{Published in:}

Nurse Education Today

\section{Document Version:}

Peer reviewed version

\section{Queen's University Belfast - Research Portal:}

Link to publication record in Queen's University Belfast Research Portal

\section{Publisher rights}

Copyright 2015 Elsevier.

This manuscript is distributed under a Creative Commons Attribution-NonCommercial-NoDerivs License

(https://creativecommons.org/licenses/by-nc-nd/4.0/), which permits distribution and reproduction for non-commercial purposes, provided the author and source are cited.

\section{General rights}

Copyright for the publications made accessible via the Queen's University Belfast Research Portal is retained by the author(s) and / or other copyright owners and it is a condition of accessing these publications that users recognise and abide by the legal requirements associated with these rights.

Take down policy

The Research Portal is Queen's institutional repository that provides access to Queen's research output. Every effort has been made to ensure that content in the Research Portal does not infringe any person's rights, or applicable UK laws. If you discover content in the Research Portal that you believe breaches copyright or violates any law, please contact openaccess@qub.ac.uk. 
Nurse Education Today, Contemporary Issues

TITLE:

Nursing, leadership and academia: Passing the baton

KEY TERMS:

Leadership, management, nursing, education, academia, succession planning

\section{Do we have a baton to pass?}

The ageing population in western nations, including the ageing nursing workforce, is a global twenty-first century problem. (Sherman, Chiang-Hanisko, \& Koszalinski, 2013). Nursing must meet the complex health needs experienced by an increasing number of older people. The related challenges, however, are nested within contemporary health systems characterised by "public sector employment moratoria, staff cuts and staffing deficits, combined with increased patient expectation, escalating healthcare costs, and a healthcare system restructuring and reform agenda" (Scott, Anne Scott, Matthews, \& Kirwan, 2014, p.1). Moreover, and unsurprisingly, the worldwide endeavour of 'workforce planning' in the health sector has been described as a "disastrous failure" (House of Commons Health Committee, 2007 , p.3). Indeed, and despite the sterling efforts of many, it is difficult to recall a time of workforce stability, predictability or adequacy. Rather, for the western nursing workforce, the phenomenon of 'feast or famine' has been the norm for decades. While some workforce strategies have been partially successful, most 
have been dependent upon the political and financial whims of notoriously transient political masters. For nursing, the need for effective workforce planning has never been stronger.

The need for workforce planning is no less pressing in the academic sector. The international research literature is largely silent, however, on effective strategies to replace current academic nurse leaders, in particular the Nursing Head of Department. This paper seeks to stimulate conversation on succession planning for the Nursing Head of Department in the academic sector and thereby encourage academic nurses worldwide to consider the issues involved. We question whether the paths taken by Nursing Heads in the twentieth century adequately address the challenges faced in the twenty-first century. We also consider how ageing academic leaders can best 'pass the baton' to the next generation of nurses, who will have a crucial role in shaping our future through education of the new workforce and the development of faculty of the future.

\section{Leadership in the nurse academic setting: Reflecting on the past}

For some clinical and educational leaders, the decades-old move by nursing from the vocational into the university sector was viewed as locational rather than educational - as business-as-usual, but in a more prestigious setting, where the old guard of the 'Sister Tutor elite' and their ilk could enjoy inflated university position titles with little or no academic track records or academic credibility (Thompson \& Darbyshire, 2013). Upon transitioning, however, many realised that for nursing, 
'doing your training' was not the same as 'going to university' (Watson \& Shields, 2009, p.47). Consequently, many of our first academic leaders were wholly unprepared for the academy's unique set of expectations and challenges. For example, as new academics, nurse educators were required to obtain higher qualifications, build the knowledge and expertise needed to develop high-quality tertiary-level undergraduate and postgraduate nursing curricula and contribute to the body of nursing knowledge through demonstrable scholarship while building their own track records of research and publications. Likewise, while learning 'on the job', many of the new Nursing Heads found themselves recruiting and developing academic teams in institutions that, at that time, often held stereotypical understandings of the role of nurses. For example, nurses have been commonly viewed as mere 'handmaidens' to the medical profession, with nursing work described as "nasty, dirty, and unpleasant tasks" (Morris, Jones \& Hunt, 2010, p.18) and, by implication, devoid of the intellectual capacity to contribute meaningfully to the evidence-base in, or development of, healthcare.

Nursing Heads additionally found themselves undertaking a range of roles with anecdotal evidence from those who assumed the new roles describing themselves as juggling front-line management, supporting and mentoring their teams to adapt to the academic environment; middle management, negotiating an unknown landscape with its own set of rules, politics, hierarchies and egos; and executive management, making high-level decisions at the organisational level while also leading the way for the nursing profession itself. There were often no local role models or mentors to guide new Nursing Heads through this transition. For many of the first Nursing 
Heads, there was no baton to receive - with leadership being something that was done in their not-so-spare-time.

\section{Nursing and academia's 'dark side'}

Nursing Heads, worldwide, have also faced with the ongoing malaise of bullying, incivility and 'gaslighting' in nursing (Thompson \& Clark, 2018) - with these behaviours remaining stubbornly endemic in both clinical and academic settings. Not only were such behaviours detrimental to those on the receiving end, they also blighted the profession's future, passing like a bad gene from generation to generation as a kind of dystopian 'rite of passage' (Birks, Budden, Biedermann, Park, \& Chapman, 2018) or 'induction process' (Enoka, 2018).

Indeed, one of the most disappointing aspects of our collective legacy is acknowledging that nursing leaders generally have largely failed to stamp out bullying from both the academy (Kolanko et al., 2006) and healthcare settings (Darbyshire, Thompson, \& Watson, 2019b). Significantly, students and faculty today have the same repository of 'horror stories' about appalling behaviour, culturally normalised incivility and overt malevolence from supposed peers and colleagues to those we ourselves heard or experienced 30 or 40 years ago. This makes it all the more galling to read calls for nursing to return to the rose-tinted, imaginary 'good old days' (Birks et al., 2018; McKenna, Thompson, Watson, \& Norman, 2006) that may never have existed. 


\section{The challenges facing contemporary Nursing Heads of Department}

The major issues faced by Nursing Heads and their academic teams in the past are, perhaps, not so different to those of today. For example, Nursing Heads continue to find themselves undertaking a range of roles, with some Nursing Heads overseeing a School and others an entire Faculty, each with different levels of responsibility and accountability. There are also short-term and long-term challenges associated with the recruitment of high-quality nurse academics, particularly members of the professoriate who can or are willing to support Nursing Heads in their roles. For example, while nursing has established itself in the academy, with its own unique body of knowledge, novice nurse academics are more likely to enter the university sector with little understanding of what it means to work in this unique environment. The considerable knowledge and expertise of a clinician or clinical educators is often deemed to be of little value by some members of the wider academy - the wellknown expert-to-novice phenomenon (McArthur-Rouse, 2008). Additionally, to echo past patterns, many novice nurse academics find themselves in a situation where they must complete higher degrees as they take on their new roles; write undergraduate and postgraduate education curricula and/or programs of study with a limited understanding of the process; and develop an academic profile by engaging in the research, grant funding and publications worlds for which they are often illprepared (Mintz-Binder, 2013).

This situation raises questions about the continuing clinical-academic 'divide' (Bennett, 2017). For example, how can the profession, including Nursing Heads, better prepare clinical nurses or clinical nurse educators for the academic setting? 
Concurrently, how can Nursing Heads also effectively mentor novice nurse academics to understand what it means to be a 'career academic', rather than simply an 'academic educator'? For example, academia comes with its own personal and political imperatives. How, then, can new academics be supported to negotiate this new and, in the $21^{\text {st }}$ Century, changing environment (McArthur-Rouse, 2008)?

\section{The Role of the Nursing Head of Department}

Many nurse academics who aspire to be a Head of Department may also have particular ideas of the role and what it means to be an academic leader consequently, once in the role, they may feel overwhelmed, ill-prepared and unsupported (Fang \& Mainous, 2019). This situation perhaps reflects perceptions in the nursing profession that the 'real power to change things and make a difference' is but one more promotion away - only to become disappointed and disillusioned when such power is found to be illusory (Darbyshire \& Thompson, 2018). For example, such perceptions misunderstand how power operates in universities, with aspiring and actual nurse leaders actively encouraged to access information on a bewildering range of 'leadership models' and programmes promising 'solutions' to effectively lead teams and bring about change in an ideal world. In contrast, they are not informed that the 'leadership industry' "has failed over its roughly forty-year history to in any major, meaningful, measurable way improve the human condition." (Kellerman, 2014, p.3) - despite the staggering $\$ 45$ billion annually poured into this black hole of ego and delusion (Howden, 2016). Moreover, and rather than achieving authentic and much needed change in the academic environment, high levels of energy are expended on managing personalities and negotiating ambiguity; 
ploughing through the ever-growing demands of managing educational administration and burgeoning burdens of compliance and juggling diminishing budgets while maintaining that standards are unaffected. Moreover, this reality can leave little time to maintain or develop a profile as both an academic and professional leader. It is perhaps unsurprising, then, that some Nursing Heads, like many of their staff, report feeling under-valued, overworked, ill-prepared and highlystressed in their roles (Mintz-Binder, 2013).

\section{The changing face of universities in the 21st century: Adapting, influencing and shaping}

Recent changes in the tertiary education sector worldwide, present a range of complex challenges to Nursing Heads. Higher education is now a billion-dollar business and export earner, with all that this entails. Indeed, for many nurses in academia, the strip-mining of university standards, values and ethos has left them wondering why they fought so hard for nursing to gain entry to the university, all those decades ago. Such views are supported by the wider discussion related to the debasement of universities, worldwide, into 'corporate degree-mills' (Rolfe 2013; Rolfe 2019), with Heads of Departments across all health disciplines have experienced decades of capricious, evidence-free, incalculably costly, wholescale 're-disorganisations' (Hunter et al., 2015; Smith, Walshe, \& Hunter, 2001), 'restructurings', 'transformational strategies', 'shared services mergers' (Shields, 2018), enforced redundancies, increasing casualisation (Klopper \& Power, 2014), and exploitation of academic staff. 
To exemplify, the current business model that drives the university sector has led to an unabashed abandoning of tenure or continuing contracts. Within this model, many institutions deem it as far better to have insecure, dependent and less powerful faculty delivering the requisite 'customer satisfaction'. This has resulted in a reduced 'buy-in' to the academic role, together with a lack of consistency and quality in the delivery of some programs of study. In essence, today's universities have essentially met government targets and paid for the expansion of higher education and increased student numbers through the creation of a new faculty "precariat" (Courtois \& O'Keefe, 2015, p.43) - or, what Parfitt calls, a "new layer of throwaway academics" (Parfitt, 2018, p.224).

Concurrently, many Schools of Nursing within universities, enjoy a 'cash cow' status - with this particular cash cow often 'fed on starvation rations' while it supports the financial viability of the wider university business. It is argued that increases in enrolments into nursing degrees have been driven by the continuing demand from the health sector to grow the nursing workforce - an argument that is countered by the growing reliance on the income motherlode of international enrolments in coursework degrees, including nursing, to remain financially viable (Australian Broadcasting Corporation, 2019). This situation has created a student cohort that, in some universities, is characterised more by quantity than quality, together with educational approaches that are more aligned with the vocational sector than the academy. Moreover, any mention of "dumbing down" (Darbyshire, Thompson \& Watson, 2019a, p.1) means a possible HR department alert or even a lawsuit (Knaus, 2019). It is perhaps unsurprising, then, that few will openly discuss the 
failure to fail (students or faculty) (Hughes, Mitchell, \& Johnston, 2016) or the "ongoing problem" (Elie, 2017) of grade inflation - i.e. the upward trend in the average grades awarded to students. Indeed, such problems, together with the need to keep our customers very satisfied indeed is now so blatant that, in the UK, recent figures showed an increase of $80 \%$ in the number of 1 st Class degrees awarded in only seven years (Weale, 2019)

The surprise, of course, is that anyone is surprised. This is a logical and perfectly predictable development for organisations that do not want to disappoint their paying customers. Were students to think that they may not receive what they have paid for, they may take their fees and go elsewhere. Likewise, if a university's standing depends on the 'number of firsts' that it awards, or if this 'excellence' is page one of their marketing brochure, or if it garners points any of the today's countless 'assessment exercises', why would any neoliberal university suddenly resist 'market forces' at this late stage of the game (Ball 2012)? At one time, the university was commonly described as a place of learning, inquiry, scholarship, challenge and personal growth - but with changing political and economic imperatives, descriptions are less positive, including a cultural and educational Aleppo: the 'university in ruins' (Readings, 1997).

Small wonder then, that some Nursing Heads express concerns about the future, including the calibre of graduates and how best to advance the professional profile, reputation and body of knowledge of nursing. In a cultural and educational Aleppo, how can we continue to educate clinically-focussed, critically-thinking nurses to meet 
the ever-growing and complex health needs of an aging population? How can we provide the necessary educational support to foster the development of high-quality nursing supervisors, managers and educators? How best can we shape the career expectations and professional opportunities of future generations of academic nurses, while at the same time providing the quality education that will enable nurses to meet the many health and social care needs of those people and their communities we serve?

To answer these questions, there is a need to pause and, in light of our espoused history of self-examination and critical thinking, ask ourselves, has the move by nursing into the tertiary education sector met its original aims and expectations? Has it resulted in the higher levels of professionalisation, knowledge, skill and respect that were expected? Do students have the time, space and challenges needed to focus and reflect upon their learning and thereby develop the muchneeded capacity to think critically and problem-solve? Is the intellectual and practicerelated life of students much different in the twenty-first century from the life of students in the late twentieth-century? If not, what influence can be exercised by future Nursing Heads, to address, adapt to or even confront changes in the university sector?

\section{The academic leaders of the future: Is there hope?}

Despite the many challenges involved, the role of Nursing Heads in the academic sector can be fascinating and rewarding, with the potential to 'make a difference' to 
the profession of nursing. Nursing Heads can model, promote and encourage the collegiality, civility, high standards, service ethos and scholarship that should exemplify the best of the academy and of nursing. Perhaps we must accept that healthcare and universities have become businesses and we are now an ineluctable part of that business world. If this is the case, then Nursing Heads - together with nurse academics - must be absolutely clear about the true nature of the business that we are in. It is not the money-making business, nor the 'bums on seats' business, nor the 'uberification' (Hall, 2016) of nursing or academia business. Rather, we are in the 'changing people's lives' business - the "transformation business" (Darbyshire, 2011, 724).

There are already glimmers of light appearing in the academy that offer hope for the future. For example, could nursing's academic leaders of tomorrow build on the clarion call for radical change issued by the rector of Ghent University in Belgium? Ghent is 'returning the university to the academics' and 'deliberately choosing to step out of the rat race between individuals, departments and universities (Redden 2019). What can nursing's academic leaders learn from this change in direction and how could they likewise support the profession to embrace such initiatives?

For those who aspire to the role of Nursing Head, it is important that they pause, reflect, and consider the reality of the role honestly - remembering there are other avenues and opportunities in academic, professional, policy or regulatory settings that will enable nurses to lead and make meaningful change. Ask what is motivating you to consider this role? To whom have you spoken about your aspiration? Is that 
someone willing to challenge you - rather than tell you what you would like to hear? On a professional and personal level, how will you deal with the business model driving academia, including the ambiguity, conflict and compromises you will face daily? Likewise, how will you negotiate the changing expectations and needs of health services? Who will you approach to be your mentor?

No less important are questions for current Nursing Heads. For example, what are you doing to mentor the next generation of academic nurse leaders? What is your succession plan and how you are enacting it? What are your approaches to promoting and championing the value, visibility, diversity and rightful place of nursing and midwifery within the academy and do you do this without downplaying or demeaning the role and place of others? How will you promote and enable tomorrow's collaborations, connections and networks within nursing, with our colleagues in other disciplines and with the patients, clients and communities that we serve? These future connections will be less hierarchical, bureaucratic and formalised and much more fluid, social, virtual and organic. They will demand a different approach, that the traditional 'command and control' paradigm could barely imagine. For retiring Nursing Heads, the questions are more profound. What does 'passing the baton' mean to you? How can you encourage current and future Heads to reflect on past achievements, failures and unresolved challenges - without expecting to find solutions for the future in that past?

Our health and university sectors have changed dramatically over the past few decades and none, but the most avid crystal-ball gazers would confidently predict 
the shape of future decades. There are many challenges to which tomorrow's faculty and Nursing Heads must rise. Some foundational aspects of nursing, education and healthcare will remain elemental. Patients and families expect to be cared for by nurses with compassion, thoughtfulness, ethical comportment, empathy, creativity, problem-solving abilities and intelligence. There is no either/or 'choice' to be made between intelligence and/or caring. Educating such well-rounded nurses requires similar pedagogical approaches and systems. A standards-free, 'tick-box' degreefactory, divorced from the worlds of service, practice and wider society and obsessed with the minutiae of 'regulating' or 'policing' their students, has no hope of creating the nurses of the future, the nurses who will be caring for us.

\section{REFERENCES}

Australian Broadcasting Corporation (2019). "Cash Cows: 4 Corners". Accessed 19 January 2019 from: https://youtu.be/Sm6IWJc8KmE.

Ball, S. J. (2012). Performativity, Commodification and Commitment: An I-Spy Guide to the Neoliberal University. British Journal of Educational Studies, 60(1), 17-28. https://doi.org/10.1080/00071005.2011.650940

Bennett, L. (2017). The gap between nursing education and clinical skills. ABNF Journal, 28(4), 96-102.

Birks, M., Budden, L. M., Biedermann, N., Park, T., \& Chapman, Y. (2018). A 'rite of passage?': Bullying experiences of nursing students in Australia. Collegian , 25(1), 45-50. https://doi.org/10.1016/j.colegn.2017.03.005 
Courtois, A. D. M., \& O’Keefe, T. (2015). Precarity in the ivory cage:

Neoliberalism and casualisation of work in the Irish higher education sector. Journal for Critical Education Policy Studies, 13(1). Retrieved from http://discovery.ucl.ac.uk/id/eprint/1538710

Darbyshire, P. (2011). The business of nurse educators in troubled times. Nurse Education Today, 31(8), 723-724. https://doi.org/10.1016/j.nedt.2010.12.006

Darbyshire, P., \& Thompson, D. (2018). Gosport must be a tipping point for professional hierarchies in healthcare. BMJ , 363, k4270. https://doi.org/10.1136/bmj.k4270

Darbyshire, P., Thompson, D. R., \& Watson, R. (2019a). Nursing schools: Dumbing down or reaching up? Journal of Nursing Management, 27(1), 13. https://doi.org/10.1111/jonm.12730

Darbyshire, P., Thompson, D. R., \& Watson, R. (2019b). Nursing's future? Eat young. Spit out. Repeat. Endlessly. Journal of Nursing Management. https://doi.org/10.1111/jonm.12781

Elie, M. (2017). Grade Inflation in Nursing Education: Proposed Solutions for an Ongoing Problem. Nursing Forum, 52(4), 387-391. https://doi.org/10.1111/nuf.12152

Enoka, M. (2018, April 3). Nursing can't shake its bullying problem. Retrieved 27 July 2019, from Radio New Zealand (RNZ) website: https://www.rnz.co.nz/news/the-wireless/375193/nursing-can-t-shake-itsbullying-problem?utm_source=redirect\&utm_medium=wireless.co.nz 
Fang, D. \& Mainous. R. (2019). Individual and institutional characteristic associated with short tenures of deanships in academic nursing, 67(5), 578-585.

Hall, G. (2016). The Uberfication of the University. Minneapolis: University of Minnesota Press. Retrieved from https://play.google.com/store/books/details?id=gil0DwAAQBAJ

Howden, D. (2016). The leadership illusion. Workable Magazine. Accessed 19 January 2019 from: https://resources.workable.com/blog/failures-ofleadership-industry.

House of Commons Health Committee. (2007). Workforce Planning Fourth Report of Session 2006-07 Volume I (No. HC 171-I ; Vol. 1). Retrieved from UK Government website: https://publications.parliament.uk/pa/cm200607/cmselect/cmhealth/171/171i .pdf

Hughes, L. J., Mitchell, M., \& Johnston, A. N. B. (2016). 'Failure to fail' in nursing - A catch phrase or a real issue? A systematic integrative literature review. Nurse Education in Practice, 20, 54-63.

https://doi.org/10.1016/j.nepr.2016.06.009

Hunter, D. J., Erskine, J., Small, A., McGovern, T., Hicks, C., Whitty, P., \& Lugsden, E. (2015). Doing transformational change in the English NHS in the context of 'big bang' redisorganisation: Findings from the North East transformation system. Journal of Health Organization and Management, 29(1), 10-24. Retrieved from https://www.emeraldinsight.com/doi/abs/10.1108/JHOM-01-2014-0019 
Kellerman, B. (2014). Kellerman B (2014) Hard Times: Leadership in America. Stanford Business Books. pp.382 Available at:

https://www.amazon.co.uk/Hard-Times-Leadership-Barbara-Kellermanebook/dp/B00RM5Z4PC/ref=sr_1_1 ?keywords=9780804793018\&linkC ode $=$ qs \&qid $=1570483477 \& s=$ books $\& s r=1-1$.

Klopper, C. J., \& Power, B. M. (2014). The Casual Approach to Teacher Education: What Effect Does Casualisation Have for Australian University Teaching? Australian Journal of Teacher Education, 39(4), n4. Retrieved from https://eric.ed.gov/?id=EJ1017621

Knaus, C. (2019). Murdoch University sues whistleblower are comments on international students. The Guardian. Accessed 19 January 2020 from: https://www.theguardian.com/australia-news/2019/oct/11/murdoch-university-sueswhistleblower-after-comments-on-international-students

Kolanko, K. M., Clark, C., Heinrich, K., Olive, D., Serembus, J. F., \& Sifford, K. S. (2006). Academic dishonesty, bullying, incivility, and violence: Difficult challenges facing nurse educators. Nursing Education Perspectives, 27 (1), 34. Retrieved from http://www.freepatentsonline.com/article/NursingEducation-Perspectives/142786655.html

McArthur-Rouse, F. J. (2008). From expert to novice: an exploration of the experiences of new academic staff to a department of adult nursing studies. Nurse Education Today, 28(4), 401-408. https://doi.org/10.1016/j.nedt.2007.07.004 
McKenna, H., Thompson, D., Watson, R., \& Norman, I. (2006). The good old days of nurse training: Rose-tinted or jaundiced view? International Journal of Nursing Studies, 43(2), 135-137. https://doi.org/10.1016/j.ijnurstu.2005.09.007

Mintz-Binder, R. D. (2013). From frontline nurse managers to academic program directors: research, strategies, and commonalities. Nursing Forum, 48(2), 114-124. https://doi.org/10.1111/nuf.12016

Morris, V., Jones R., \& Hunt, A. (2010) Nursing and nurses: The image and the reality. Nursing Management, 17, 1, 16-19.

Parfitt, S. (2018). Academic Casualization in the UK. International Labor and Working-Class History, 93, 221-227. https://doi.org/10.1017/s0147547917000369

Readings, B. (1997). The University in Ruins. Harvard University Press.

Redden, E. (2019). Stepping out of the race race. Inside Higher Ed. Accessed 19 January 2020 from: https://www.insidehighered.com/news/2019/01/23/ghent$\underline{\text { university-belgium-embraces-new-approach-faculty-evaluation-less-focused }}$

Rolfe, G. (2013). The University in Dissent: Scholarship in the Corporate University. Retrieved from https://market.android.com/details?id=book68r7X7RvuZEC

Rolfe, G. (2019). Carry on thinking: Nurse education in the Corporate University. Nursing Philosophy: An International Journal for Healthcare Professionals, e12270. https://doi.org/10.1111/nup.12270 
Scott, P. A., Anne Scott, P., Matthews, A., \& Kirwan, M. (2014). What is nursing in the 21 st century and what does the 21 st century health system require of nursing? Nursing Philosophy, Vol. 15, pp. 23-34. https://doi.org/10.1111/nup.12032

Sherman, R. O., Chiang-Hanisko, L., \& Koszalinski, R. (2013). The ageing nursing workforce: a global challenge. Journal of Nursing Management, 21(7), 899-902. https://doi.org/10.1111/jonm.12188

Shields L, \& Darbyshire, P. (2018, August 21). Shared university services 'snake oil': Retrieved 28 July 2019, from Campus Review website: https://www.campusreview.com.au/2018/08/shared-university-servicessnake-oil-opinion/

Smith, J., Walshe, K., \& Hunter, D. J. (2001). The 'redisorganisation' of the NHS. BMJ , 323(7324), 1262-1263. https://doi.org/10.1136/bmj.323.7324.1262

Thompson, D. R., \& Clark, A. M. (2018). Leading by gaslight? Nursing's academic leadership struggles. Journal of Advanced Nursing, 74(5), 995997. https://doi.org/10.1111/jan.13399

Thompson, D. R., \& Darbyshire, P. (2013). Is academic nursing being sabotaged by its own killer elite? Journal of Advanced Nursing, 69(1), 1-3. https://doi.org/10.1111/j.1365-2648.2012.06108.x

Watson, R., \& Shields, L. (2009). Cruel Britannia: A personal critique of nursing in the United Kingdom. Contemporary Nurse, 32 (1-2), 42-54. Retrieved from http://eprints.whiterose.ac.uk/9819/1/Watson1.pdf 
Weale, S. (2019). Government calls on OfS to clamp down on university grade inflation. The Guardian. Access 19 January 2020 from:

https://www.theguardian.com/education/2019/jul/11/government-calls-on-ofs-toclamp-down-on-university-grade-inflation

Wolff, A. C., Regan, S., Pesut, B., \& Black, J. (2010). Ready for what? An exploration of the meaning of new graduate nurses' readiness for practice. International Journal of Nursing Education Scholarship, 7(1), 1-14. https://doi.org/10.2202/1548-923X.1827 